\title{
Correspondence
}

\section{The Moplah Outbreaks: A Discussion Contribution}

Professor Stephen Dale's article on the Moplah (or Mappilla) outbreak (JAS, November 1975) is welcome. It is a stimulating contribution to the investigation of a phenomenon which should be instructive to all those concerned with the role of religion in social conflicts. Having worked on the Moplah question myself and having come to conclusions different in important respects from Dale's, I should like to make a contribution to what I hope will be a continuing discussion. For a fuller statement of my views, see my Ph.D. thesis "The Moplah Rebellion of 192I-22 and Its Genesis" (London, 1975).

Dale speaks of the Moplah ulema as "the single, critical determinant" of the Moplah outbreaks and claims that "it is the content and idiom of their teaching that best explains the diverse causes and peculiar characteristics of these incidents, as well as their frequency and location." It is true that, in a number of outbreaks though apparently not in all of them, the participants had previously secured the sanction of Moplah ulema. It is true that, in all outbreaks, the participants seem to have believed that what they were doing was legitimate according to the canons of Islam. It is true that certain ulema, and especially Syed Fazl, the Tangal (Sayyid) of Mambram, were propagating the ideas that it was a merit to kill a landlord who evicted and that he who died fighting after killing infidel oppressors would be rewarded in paradise. It is true that, in a few cases, Moplah ulema actually became participants in and even leaders of outbreaks. Even so, I would dispute the claim that any of this can be taken as demonstrating that the ulema were the determining factor in the outbreak and that their teaching explains the chief characteristics of the phenomenon.

In fact, the theory that a school of ulema with what Dale calls a "revivalist ideology" was responsible for outbreaks - far from explaining the essential characteristics of these disturbances-seems to beg the most important questions about them. This, I think, is shown by a consideration of questions that the incidence of outbreaks raises: Why did these ulema induce outbreaks only from 1836 , or whenever Dale considers outbreaks to have begun? Why did they not bring them about during the period $1898-1915$ (when none of these disturbances occurred) or, indeed, after 1919 (when the last outbreak was perpetrated)? Why, if the ulema were the determinant, did outbreaks occur only in one part of Malabar inhabited by Moplahs, the rural areas of the southern interior, mainly in Ernad taluk? To respond that the particular "school" of ulema that was "causing" outbreaks existed only in one particular time and place is, again, merely to beg the question why?

My own research has led me to the conclusion that the relationship between the ulema and the lay Ernad Moplah rural population responsible for committing outbreaks was by no means the largely one-way, manipulative one suggested by Dale's analysis. The ulema's role in sanctioning disturbances perpetrated in the name of the vindication of "Islam" (or, more precisely, the community in which that religion was embodied in 
Ernad $^{1}$ ) was important. However, there is strong evidence that, in doing so, they were responding to a demand from the lay Moplahs of rural Ernad. These latter, in the outbreak period of $1836-1919$, were faced with the burgeoning of the power of the highcaste Hindu, power based on a virtual monopoly of large landownership; nearly all the great jenmis (landlords) of Malabar, and especially south Malabar, were high-caste Hindus. In $1788-89$, the rural-Ernad Moplahs had benefited from the removal of the jenmis and their demands, when large numbers of the high-caste Hindus of Malabar had fled from a forcible conversion campaign conducted against them by their Muslim ruler Tippu Sultan. The defeat of Tippu by the British, and the establishment of the rule of the East India Company in Malabar in 1792, had paved the way for the return of the jenmis to their estates. Moreover, British rule extended to the jenmi the novel power, backed by a powerful judicial and administrative apparatus, to regulate his rent and other demands entirely according to the dictates of the market. My belief is that, under these conditions of the extension of jenmi power under British rule, the outbreak functioned as a means of curbing the exercise of that power; it was a means of terrorizing the powerful high-caste Hindus of Ernad for the benefit of those Moplahs subordinate to them. As was noted in 1849 , the "fear of the Hindoo" in the outbreak zone "acts as a great check against much abuse and that as a general rule he does not press for his rights with the same energy as he would in a more quiet part of the Country." 2

I consider that outbreaks were committed not because a particular group of ulema took it into their heads, for reasons best known to themselves, ${ }^{3}$ to start a "revivalist" movement. Outbreaks wete committed because they fulfilled a particular need of a particular group of Moplahs in a particular time and place. Of course, it is possible to argue that, since the ulema were the source of the religious sanction necessary before an outbreak could occur, they were in a position to control the outbreak and that, in this sense, they were a determining factor. I believe that such a conclusion would be unwarranted. Moplah "divines" were themselves usually dependent on the goodwill and material support of their following; in Ernad, Mussaliars (moulvis) were chosen and fed by the local Moplahs. Even the famous Mambram Tangals had no apparent property; they professed to be fakirs, and were supported by "the voluntary oblations of their followers." The material dependence of the ulema on their Moplah congregations was a barrier to any tendency among those "divines" working in the outbreak zone ${ }^{5}$ to oppose

${ }^{1}$ To be even more accurate, even certain groups of Ernad Moplahs. such as the Kondotti Moplahs discussed in footnote 9, would have to be excluded.

${ }^{2}$ Remarks of H.V. Conolly, Malabar Collector [hereafter M.C.], in appendix 2, Conolly to Sec., Judicial, 12 Oct 1849, Madras Jud. Proceedings (MJP) no. 794, I Dec I849, p. 4787.

${ }^{3}$ It is true that Dale (p. 90 ) speaks of the Mambram Tangal perceiving "evictions as one of a number of related issues that threatened the integrity and prosperity of the Muslim community in Malabar." However, I understand Dale's article to be claiming that the outbreak was not fundamentally a response to the earthly problems of the Moplah, but was called into being because of the "revivalist ideology" that is said to have gripped certain ulema. One is left with the impression that the earthly problems were quite secondary, that almost any issue in any time and place, as long as it involved Hindus and Mus. lims, would have been grist to the mill.

${ }^{4}$ Conolly to Sec., Jud., 4 Nov 1843 , MJP no. 69 , $27 \mathrm{Jan} 1844$, p. 197.

${ }^{5}$ Far from the ulema who belonged to what Dale calls the "Ponnani faction" of Moplahs being "a small group of Mappilla religious leaders" (p. 93), all Moplahs of South Malabar (except the Kondotti Moplahs discussed in footnote 9) were referred to as "Ponnani Moplahs" since, nominally, they owed allegiance to the Valiya Jaratingal Tangal of Ponnani (C. A. Innes, Malabar Gazetteer, Madras, 1951, vol. I, p. 188). The category of ulema in Ernad from which shabid might obtain sanction was indeed the "Ponnani" priesthood. However, these constituted the whole of the ulema of the area except the small minority attached to the Kondotti Tangal. 
Moplah "fanaticism." It was noted in 1885 of those Ernad ulema who, at that time also, were sometimes suspected of being the prime movers behind outbreaks, that "they are so circumstanced that, to retain their hold on the people and to secure the comfortable in comes derived from them, they are forced to go with them in this popular movement."

On the other hand, lay Moplah do not seem to have been greatly constrained, in their pursuit of what was regarded as the interests of the community, by the ties binding Moplah congregations to the ulema. Instances sometimes occurred in which outbreak participants paid no heed to the appeals of "divines" to surrender. On another occasion, certain Moplahs in collision with their jenmi over their acquisition of land for a mosque site, publicly tore up with contempt an ulema ruling that was against their contention that a mosque-once established-might under no circumstances be removed. ${ }^{7}$

It is true that outbreaks were confined to the Moplah community even though Hindus, quite as much as Moplahs, experienced the adverse exercise of jenmi power. However, this was not because Moplahs were subject to the machinations of the ulema, or directed, regardless of their interests, by a perverse fanaticism. I believe that the religion of the Moplahs provided a means, unique in nineteenth-century Malabar, for mobilizing against the jenmi power. The conditions of life and work in Ernad entailed a degree of isolation for the rural subordinate, making such mobilization on a secular basis extraordinarily difficult. The Muslim section of the population, however, was distinguished by an unsegregated structure of religious association (and especially its congregational form of worship), compared with that of the Hindu. This must have been partly responsible for the greater sense of intra-community solidarity and, therefore, indepen. dence from local non-Muslim authority, for which the Moplah was celebrated. During the period of the outbreak, the mosque proved to be most useful as an aid to the confederation that was normally a preliminary to the disturbance itself. Thus, the 1885 Ponmundam outbreak was plotted in a mosque, after services, by members of its congregation. ${ }^{8}$ In the case of most outbreaks, the participants were drawn largely from single mosque congregations.

For the Hindu social orders subordinate to the high-caste jenmi, there was no comparable form of religious organization on a congregational basis; their capacity to combine was restricted by the observance of the demands of caste hierarchy and exclusiveness. The religion of these sections of the rural subordinate, far from presenting opportunities to resist jenmi power, bound them the more securely to their high-caste landlords. For the Hindu there was no possibility of sanction from bis religious superiors for resisting the rural magnates who, indeed, were often one and the same person; many jenmis were Brahmins. The low Hindu rustic exercised no economic control over his source of religious dispensation; he was himself subject to a very material dependence on that same source. Should he incur the displeasure of his Brahmin jenmi, he was liable to an excommunication that was not only religious but also social and economic; the jenmi might have him evicted and subjected to social boycott. Under these circumstances he was far more likely to be a tool of the jenmi than a rebel against him. ${ }^{9}$ The challenge to

\footnotetext{
${ }^{6}$ W. Logan, M.C. to Chief Sec., I7 July I885. MJP no. 2725,8 Oct 1885 , p. 7 .

${ }^{7} \mathrm{~W}$. Logan, "Report on Malabar Land Ten. ures," Govt. of Madras, Malabar Special Commis. sion, $1881-82$ (Madras, 1883), vol. I, pp. Ixxii-lxxiii.

${ }^{8} \mathrm{P}$. Karunakara Menon, Deputy Magistrate, Southern Division to W. Logan, M.C., I July I885,
}

MJP no. 2725.8 Oct 1885 , p. 6.

${ }^{8}$ Significantly, in the case of the one important example of an Ernad Tangal who was freed from dependence on his lay followers by land grants from the government, the Kondotti Tangal was able to keep the Moplahs of his area in check. Throughout the period of Moplah outbreaks, the Moplah depen. 
jenmi power had to be mounted not through a purpose-built organ of struggle but through a religiously defined community. This, I consider, was one reason for the notorious Moplah zeal for proselytizing; conversion curbed the field of power of the high-caste jenmi. On the other hand, the presence of Hindu subordinates tended to be a source of strength to landlords. This was demonstrated in 1920 when a jenmi was able to break a "strike" by his Moplah tenants, who were refusing to take up the plot of an evicted co-religionist, by inducing a Hindu to accept the lease. ${ }^{10}$ The low Ernad Moplah had sound material reasons for encouraging Hindus to convert, and for discouraging converts from reverting to their old religion. Apostacy, seen as a threat to the community, was always likely to elicit a frenzied response from the Ernad Moplah. I believe that those outbreaks directed against humble apostates functioned as a means of ensuring solidarity - of strengthening the "horizontal" links between Moplah and Moplah at the expense of the "vertical" ones between the jenmi and his Hindu dependents. The "fanaticism" of the Ernad Moplah is best understood in terms not of perversity but of pursuit of advantage.

Such a view of the Moplah outbreak offers a more convincing means of explaining characteristics of the phenomenon (such as its incidence) than by reference to a supposed directing influence of the ulema. Thus, it is true, as Dale states, that outbreaks occurred less often after the mid-1850s than before. However, this can hardly be because of the removal from Malabar of Syed Fazl in I852. As Dale himself points out, there still remained in Ernad other "divines" who were prepared to sanction outbreaks and bless participants. On the other hand, in 1854 the Government of Madras had passed the.punitive legislation known as the "Moplah Acts," providing for the collective fining of the Moplahs of areas involved in outbreaks, the confiscation of the property of shabid, and the indefinite deportation of anyone merely suspected of being involved in outbreak plots. These provisions were calculated to make the Ernad Moplah community more cautious in its encouragement of outbreaks. In fact, after 1854 it was not unusual for outbreak plots to be thwarted by Moplahs fearful of incurring the penalties of the Moplah Acts. This was the case with an outbreak plotted in 1857 at the time of the Mutiny. The Moplah Acts had first been applied in 1855-56, after H.V. Conolly, Collector and District Magistrate of Malabar, had fallen victim to an outbreak. After the very widespread finings and large-scale deportations of suspects (under the Moplah Acts) that followed the murder of Conolly, it was reported that "so far from the Moplahs designing to injure anyone, they are themselves in great fear, and overawed by the measures of Govern. ment." 11

However, since the British were unwilling to give those subordinate to the Malabar jenmi a legitimate defense against the power of the latter through measures of agrarian legislation, outbreaks continued, though on a more sparing scale. When the government, between 1887 and 1900 , finally did pass a series of legislative measures directed against jenmi power, the result was the ending of outbreaks in 1898 - for an unprecedented seventeen-year period. It is true, as Dale points out, that the Tenants' Improvements Act of 1887 was criticized by the Malabar Collector in 1894 for failing to give the Malabar tenant the security from eviction that the Act had been designed to supply. However, as

dents of the Kondotti Tangal were free from implication in "fanatical" disturbances, for the suppression of which, indeed, this Tangal was sometimes rewarded by the government.

${ }^{10}$ Administration report of the Guruvayur Deva. swom estate for 1920-21, ir Oct 1921, Madras Court of Wards. Proceedings no. 44, 16 Nov 1921, p. 2.

${ }^{11}$ T. Clarke, M.C. to Chief Sec., is May 1856 , MJP no. 607, 7 June 1856, p. 1664. 
Bradley himself allowed, the Act had "worked so far favourably for the tenants," who were "far better off than they were before the passing of the Act." On the other hand, the jenmis looked on the Act "with disfavour, as it has appreciably reduced their hold upon their tenants." 12 Further, the Tenants' Improvements Act was amended and strengthened in 1900; while in 1896 , other Government measures had, temporarily, put the jenmis in some difficulty in dealing with their tenants. The Jenmi Registration Act made necessary the ending of the traditional practice in Malabar of settling the land revenue with occupants who were not proprietors. Instead, the jenmis were ascertained, registered, and made primarily responsible for the revenue. The chorus of complaints this measure produced from the jenmis must have been to some degree genuine, since the Court of Wards administration of jenmi estates found that profits had been reduced as an initial consequence of the operation of the Registration Act. ${ }^{13}$ The problem of recovering the government demand from tenants was exacerbated by the removal of the power of distraint from the jenmi by another Act of 1896 .

In fact, the barrier to the exercise of jenmi power provided by the legislation of 1887-1900 proved impermanent; the jenmi found ways of circumventing its provisions, and outbreaks resumed in 1915. The ending of outbreaks in 1919 can be attributed to the fact that, after the First World War, the Ernad Moplah turned to other methods of prosecuting his struggle with high-caste Hindu ascendancy and the power of the British Raj that was sustaining it. In 1921-22 came the attempt of the Moplah to seize power in the "fanatic zone" of Ernad. This demonstration that Moplah discontent might take the form of rebellion created favorable conditions for the winning of more advanced tenancy legislation from the government, and a Malabar Tenancy Act was passed in 1930.

But, if outbreaks were a response to the ascent of high-caste Hindu power under the conditions afforded by British rule, why did outbreaks begin as late as 1836 , four or five decades after the East India Company's acquisition of the district? Though British rule allowed the high-caste jenmis to return from exile and reestablish themselves on their estates, their flight from Tippu Sultan in $1788-89$ left them in a weak position for decades. In 1788 , jenmis were often obliged to mortgage their lands on most unfavorable terms. In 1801, jenmi estates were so encumbered with debt that it was observed that "from the highest condition" the jenmis had been "reduced to a mere nothing but the empty Sound of Title." 14 In fact it was not until the 1820 , when a steep and long-term rise in prices for farm produce set in, that the jenmi began to recoup his fortunes and establish the ascendancy for which he was notorious in later decades.

If considering the outbreak in terms of agrarian conflict helps explain the incidence of Moplah violence in time, it is also of assistance in solving the problem of the restriction of the outbreak to the southern interior of Malabar. The attempt to account for the geographical restriction of the outbreak phenomenon by reference to the proximity of a "school" of ulema with a "revivalist" ideology seems to me unhelpful. There is nothing about doctrines in themselves (or a "school" of ulema for that matter) that they should be confined within so restricted an area. On the other hand, we can establish very good reasons why the Moplah rustic of south interior Malabar should find it more necessary

\footnotetext{
${ }^{12} \mathrm{H}$. Bradley, Acting M.C. to Sec. to Commissioners of Land Revenue, 3I Jan I894. MJP no. 2374 (Conf.), 1 Oct 1894 , p. 2.

${ }^{13}$ A. F. Pinhey. M.C. and Agent to Court of Wards to Sec., Court of Wards, 25 Oct 1902, Madras Revenue Proceedings no. 596, 13 June 1903.
}
p. 3.
${ }^{14} \mathrm{~T}$. H. Baber. Collector of Kirakumpuram. Wadakumpuram and Porawaye, to Board of Reve- nue, 31 Jan i80I. Madras Board of Revenue Pro- ceedings, 2 Mar 1801, p. 2362.


than other Moplahs in the district to resort to outbreaks to curb landlord power. The north and the coastal parts of Malabar were largely dependent on "garden" cultivation of fruit trees like the coconut. Such trees were very sensitive to the quality of husbandry, so that a jenmi was far less likely to squeeze tenants engaged in such cultivation, fearing that they might take as much as possible from their gardens and thereby ruin them. Thus, the typical agriculturalist of north and coastal Malabar had a means of defense. against jenmi power other than the terrorization wrought by the outbreak. This was not the case in south interior Malabar, where the tenants were far more often rack-rented cultivators of paddy lands. The outbreak was very largely restricted to the south Malabar interior because physical conditions meant that here the Moplah had no other means of effectively curtailing the exercise of jenmi power.

I am sure Dale is correct in stressing that agrarian conflict in Malabar existed before British rule. However, we need to know much more than we do now about the question of class relationships in rural Malabar before 1792. It would also be useful if we could trace what connections may have existed between those cases Dale mentions, Moplahs in Malabar ports in the early eighteenth century apparently seeking martyrdom after attacking Christians, and the outbreaks of rural Ernad in the 1836-1919 period. The Malappuram incident, placed in the I80os by Dale, will not help bridge the historical gap. This incident, so often placed in the nineteenth century by the authorities (e.g., C.A. Innes, author of the Malabar Gazetteer), would appear to have occurred as early as 1734 . In a little-known volume entitled Two Years in Malabar (Calcutta, 1907), a British soldier, Vincent Joseph Ryder, gave what is perhaps the only detailed account of this incident available in an English.language publication. On detachment duty in Malappuram in 1904-06, Ryder discovered from the local Moplah village headman (who in turn had access to records preserved in Malappuram mosque) that in 1734 forty-four Moplah heroes had died fighting in defense of the local mosque against a threat to it from the local great Hindu jenmi.

Further, it is necessary to recognize important differences between the 1734 incident and the outbreaks of $1836-1919$. If Ryder's account is correct, the 1734 disturbance did not begin with Moplah attacks on Hindus, as in the case of the nineteenth-century outbreaks; on the contrary, it was more in the character of a defensive action against the forces of the Hindu jenmi. Nor did the forty-four Moplah heroes deliberately set out, like the nineteenth-century shabid, to die fighting; they had apparently been besieged in the mosque they were defending, and had actually bargained for their freedom before being killed trying to break out.

British officials in Malabar tended to use the term "Moplah outbreak" to describe any act of Moplah violence they considered to be "fanatical." In my own work, I have found it useful to limit the term to those incidents in which the participants actively sought their own death in vindication, as they saw it, of local "Islam." To define Moplah outbreaks as attacks conducted as "religious acts," as Dale appears to, seems to me to obscure the distinctive features of the outbreak. These features - such as the preparations of intending shabid in divorcing their wives, paying off debts, and dedicating themselves through vow-taking ceremonies - were determined by the fact that the participants intended to die fighting. Defining the Moplah outbreak as a disturbance in which the participants devoted themselves to die fighting in defense of "Islam" permits us to demarcate the outbreak from all kinds of other "religious" acts of violence, such as the typical Indian "music before mosques" riot, which shared none of these distinctive characteristics of the outbreak. Submitted to this test, the 1847 disturbance recorded in 
Dale's list of outbreaks most clearly stands out as different from the others. Since the participants showed no intention of seeking their own death, there were none of the preparations characteristic of the typical outbreak. Moreover, the 1847 affair was an urban, not a rural phenomenon. It was simply an affray that occurred when a Moplah mob in Ponnani forcibly removed a young Muslim woman from the quarters of one Captain Partridge who was passing through the town.

In saying that the characteristic features of the outbreak were determined by the fact that participants had resolved to die fighting for "Islam," it might appear that, in this very specific sense, I am in agreement with Dale's proposition that certain religious ideas - in this case, that of the heavenly reward of the "martyr"-explain the "peculiar characteristics" of outbreaks. However, while pressing the point of view that the defining characteristic of the Moplah outbreak was devotion to death, I feel that we cannot be content with merely labeling this as a religious idea. It is most important to see the suicidal aspect of the outbreak in a social context. If the outbreak was, as I believe, a resort to desperation by the subordinate Ernad Moplahs under conditions offering no more effective methods of curbing jenmi power, then the death of each and every participant was well-suited in certain senses to Moplah needs. Certainly, the deathseeking aspect of the outbreak enabled the Ernad Moplahs to wreak the maximum terror with minimal resources. Nothing was more chilling to local Hindus than men on the rampage for whom death not only held no fears but was eagerly sought. Facing the unfailing supply of men with such singular intent, the British found it extraordinarily difficult to devise methods of discouraging outbreaks without resorting to measures, like collective fines, which they were most reluctant to employ and which could only intensify Moplah hatred of "infidel rule."

Another analytical tool that does not seem to me to be very useful, unless placed in its social context, is Dale's formulation of a "desire for martyrdom" as an "end in itself." It is true that some Moplah participants in outbreaks had not suffered personally at the hands of those who fell victim to the Moplah violence. This is not to say, however, that they might not have been generalizing to all local non-Muslims their antagonism for other "infidels" whom they felt had injured them. More important, even if certain outbreak participants had no strong feeling themselves against infidel "oppressors" of Moplahs, but were merely seeking the heavenly rewards and earthly prestige martyrdom offered, they were responding to an ideology functioning as the instrument of a community that did feel itself in antagonism with local Hindu power. The éclat the outbreak participant so typically sought provided some means of control of the outbreak for that community. It was because of the degree of social control over the outbreak that the adventitious element was not greater in a phenomenon that entailed the incitation of a wild spirit of holy wrath. Thus, no outbreaks occurred between 1898 and 1915, a period in which the rural Ernad Moplahs had some kind of legitimate defense against jenmi power. Bands of frenzied shabid tended to embark on their career of violence when the interests of the community they were vindicating dictated rather than at the caprice of individual psychopathology.

I would, finally, like to comment on the question of Moplah violence and British rule. The outbreak was a means of confronting jenmi power. At the same time it was a challenge to British rule that had permitted the jenmi to return from exile in the I790s, had placed in his hands unprecedented powers, and had stood behind him to enforce those powers. However, after the first decade or so following 1792 , when British rule in Malabar was insecure and a Moplah revolt had been staged in 1800-02, the power of the 
Raj for more than a century appeared unshakable. ${ }^{15}$ In consequence, the challenge to British rule which the outbreak represented was mere ritual. When, in 1849 , the sbabid band of one Athan Gurikal had the whole of Ernad at their feet after the complete rout of the sepoys sent against them, no attempt was made to seize control. The gang merely awaited more troops so as to die in "fair fight with the Cirkar,"16 as the Gurikal put it.

During the period of the nineteenth and early twentieth' centuries, there were signs that Ernad Moplahs were watching eagerly for the intervention of some external agency to deliver them from the British rule on which jenmi ascendancy was based. Thus, in the I840s, a Moplah millennial sect called the Hal Ilakkam predicted the imminent arrival of a mysterious ship with arms, provisions, and money sufficient to equip 40,000 men. If that number could be raised, these Halar believed, then the country might be conquered and "the Hindus would ... totally vanish." 17

A parallel may be drawn here with the work Tubfat-Al-Mujabidin, by the sixteenthcentury Moplah writer Zaynu'd-Din. It is quite possible, as Dale says, that Zaynu'dDin's call for war against the infidel Portuguese may have later been construed as sanction for the violence the nineteenth-century shabid perpetrated against Malabar Hindus. However, we can see from Zaynu'd-Din's preface to Tubfat-Al-Mujabidin that his message was for "the most illustrious of Sultans, the most notable of monarchs, one who has made the holy war his chief consolation, and holds the elevation of the word of Allah by military expeditions as a precious ornament [whose] set of . . mind is towards service to the servants of Allah [and whose] lofty courage disposes him to destroy the enemies of Allah, ... the mighty, victorious and compassionate Sultan Ali Adil Shah." 18 It would appear that whenever Moplahs were desperately weak in the face of hostile infidel power, they were liable to look outside Malabar for deliverance.

However, during the nineteenth century, British officials were well aware that, should British rule appear vulnerable, a rising by the Moplahs of the "fanatic zone" could be expected. In 1842 it had been observed that the "lower order of Moplahs and particularly those of the inland Talooks" were "not to be depended upon when an apparent opening for their acting against [the British] might occur."19 Before the Moplahs would go to the lengths of rebelling, they needed belief in the possibility of victory. They rose in revolt in 1921-22 because British rule in Malabar appeared vulnerable at a time when the Raj was opposed by the Khilafat-noncooperation movement-the first serious challenge to its existence since $1857-58$. I have come to the conclusion that the major contribution of this movement to the Moplah rebellion was not, as Dale claims, "the crucial elements of ideology and organization"; it was the Moplah belief in victory which triggered insurrection. As was observed at the time, it was

\footnotetext{
${ }^{15}$ Except at the time of the $1857-58$ Mutiny; however, no Moplah rebellion occurred at this time because the Ernad Moplahs had been intimidated by the first implementation in 1855-56 of the Moplah Acts (see above).

${ }^{16}$ Report of W. Robinson. Head Asst. Mag., Malabar, 18 Oct 1849. MJP no. 794, i Dec 1849, p. 4937. Cirkar means government.

17 "Particulars of the Hal Ilakkam among the Mappillas in Chernad Taluk and the Neighbouring Parts" by a "native subordinate," Nov 1843, in W. Logan, Nalabar, "Manual (Madras, 1887).
}

\begin{abstract}
vol. I, pp. 561-62.
${ }^{18}$ Author's preface, Shaykh Zaynu'd-Din, Tub. fat-Al-Mujabidin: An Historical Work in the Arabic Language, S. Muhammad Husayn Nainar (trans.), Madras, 1942, p. 14. Sultan Ali Adil Shah was apparently the Sultan of Bijapur (now in Mysore state) from 1558 to 1580 .

${ }^{19} \mathrm{~T}$. L. Strange, a Malabar judge, 27 May 1842 , quoted in minute of T. M. Lewin. Acting 3d Judge, Foujdaree Udalut, 30 June 1842, MJP Oct 1842, p. 4942 .
\end{abstract}


the Khilafat-noncooperation movement which had "produced an impression on the mind of the Mappilla that the end of the British Raj is at hand."20

As far as ideology is concerned, it can hardly be argued that the Ernad Moplah was a convert to the Gandhian shibboleths of nonviolent noncooperation and Hindu-Muslim unity. Further, rebel Moplah understanding of the term "Khilafat" seldom related to the misfortunes of the Caliphate at the hands of the Allies. When the Moplah rebels, the "Khilafat people," referred to their rule in Malabar as "Khilafat raj," what was meant was simply the rule of the Ernad Moplah. It did not require the propaganda of the Khilafat movement to make the "fanatic zone" Moplah believe that British rule was the enemy of Islam. Thus, the official reports on the outbreak of 1896 had revealed that remarks such as "We have had much oppression at the hands of the white folk" and "there is no room for Mussulmans in the country" ${ }^{21}$ were current among the Moplahs of the outbreak area.

As far as organization is concerned, the Khilafat movement neglected most of the "fanatic zone" until as late as June 1921, when a number of tours of the area were undertaken by two agitators. These men would pass fleetingly through a desam (village) and appoint a few Moplahs to a "Khilafat committee" which, typically, ceased to exist as soon as the agitators had passed through. As the Police Superintendent of South Malabar later complained, there was "nothing tangible to oppose." ${ }^{22}$ When the rebellion broke out in August 1921, rebel organization was not based on the ephemeral Khilafat committees and volunteer corps the Khilafat agitators had attempted to establish. The rebel organization of 192I-22 consisted essentially of a large number of highly localized "jurisdictions" apparently based on the sense of local solidarity which, over a very long period, had grown up between Moplahs living in the same locality who attended the same mosque. It is true that the more outstanding Moplah leaders like Variankunnath Kunhamad Haji and the Chembrasseri Tangal attempted to establish suzerainties, occasionally with some success, over these petty Moplah republics. Even so, the resistance of parochial prerogative often proved stubborn. Moplah raj was most effectively organ. ized within those narrow local limits that had tended to restrict the mobilization of the Moplah challenge to the jenmi in the preceding outbreak period.

The rebellion of 1921-22 constituted an attempt by the Ernad Moplah at a definitive solution to the problem of the high-caste Hindu ascendancy that had been brought by British rule. Professor Dale is surely correct in cautioning against any exclusively economic interpretation of the Moplah violence in the south Malabar interior from $179^{2}$ to 1922 , but at the same time I feel that his own analysis is weakened to the extent that it is not based on an examination of the Ernad Moplahs' sense of their own interests and their attempt to further the same.

\section{London}

CONRAD WOOD

\footnotetext{
${ }^{20}$ Govt. of Madras to Govt. of India, 17 Aug 1921, quoted in speech of Sir W. Vincent, 5 Sept 1921, Council of State Debates, vol. II, 2d session, 1921, p. $9^{2}$.

${ }^{21}$ Report of H. M. Winterbotham, formerly M.C., 10 Apr 1896, L/PJ/6/422, 996/96, pp. 12, 16,
}

18.

${ }^{22}$ R. H. Hitchcock, A History of the Malabar Rebellion, $19^{21}$ (prepared under the orders of the Govt. of Madras and printed in 1925 but not pub. lished), p. 20. 